\title{
THE EFFECT OF FINANCIAL DISTRESS OF THE ALTMAN, SPRINGATE, AND ZMIJEWSKI MODELS ON STOCK RETURNS OF INDONESIAN TRANSPORTATION ISSUERS IN 2016-2020
}

\author{
Abdi Putra ${ }^{1}$ Rangga Putra Ananto ${ }^{2}$ Randy Heriyanto ${ }^{3}$ \\ Padang State Polytechnic, Indonesia \\ Email: abdiputramc@gmail.com, Rangga@pnp.ac.id, \\ Randy@pnp.ac.id
}

Keywords

Financial Distress,

Altman, Altman

Modified,

Springate,

Zmijewski, Stock

Prices, Stock

Returns, Failure,

Bankruptcy,

Financial

Performance,

Financial Difficulties

\section{Article Info}

Accepted:

November, $24^{\text {th }} 2021$

Revised:

December, $4^{\text {th }} 2021$

Approved:

December, $13^{\text {rd }}$

2021
Abstract Financial distress is a condition where the company is unable to fulfill its obligations. This is usually accompanied by consecutive negative earnings. The transportation sector is one sector that is vulnerable to experiencing financial distress. This is due to the many new, more innovative competitors. As well as regulatory policies that are not in favor of this industry. Therefore, the burden borne by the company is not proportional to the income earned, resulting in financial difficulties. To measure this financial distress, the author uses several models such as: Altman model, Springate model, and Zmijewski model. This study examines the effect of financial distress from each of these models on stock returns. The data used in this study comes from financial reports and other financial data for the period 20162020. The results showed that there was no significant effect of the Altman, Springate, and Zmijewski models of financial distress on stock returns in this sector.

\section{Introduction}

The transportation company is a company that has a large number of fixed assets. Therefore, the transportation company has a fairly large 
depreciation expense on these fixed assets. This is a challenge for business people in this sector. As a company engaged in the service sector, of course, the quality and innovation of service will have an impact on the customer's choice of the company. The company's ability to acquire these customers has an impact on the company's revenue. Companies that are not able to compete in providing services to customers cause the company to record revenues that are not commensurate with the burdens that must be borne. This will cause financial difficulties for the company.

In recent years, transportation companies have experienced a "depression" due to the presence of new competitors and the effects of the pandemic. The presence of online transportation has an impact on conventional transportation income. According to (Hendrayanti, 2018), 88.86\% switched to using online transportation. A total of $20.46 \%$ of $88.86 \%$ are conventional taxi users. Online transportation is more desirable than conventional transportation because it is practical, cheaper and certain. Online transportation resulted in a decrease in conventional transportation income in the City of Kediri (Mukaromah, Yuliari, \& Arifin, 2019).

Service users who tend to decline are a threat to the sustainability of transportation companies. The decrease in service users will have an impact on decreasing the company's revenue. Decreased income will increase the expense ratio even greater. The growing load ratio is a threat that is quite difficult for transportation companies to control. This is because transportation companies have a very large fixed asset value in the form of vehicles compared to other assets. This large fixed asset will have a large impact on the depreciation expense of fixed assets. In addition, the large fixed asset maintenance costs must also be borne by the company. Therefore, if the income tends to decrease, the profitability and solvency of the company will get worse. If this condition continues, financial distress will occur and the potential for bankruptcy will occur. For this reason, it is necessary to analyze financial distress by stakeholders before making investment or managerial decisions in a company.

According to Ramadhani \& Lukviarman (2009) financial distress is the stage of decreasing the financial condition of a company prior to bankruptcy or liquidation. The financial distress model has been used to analyze the performance of companies from different industries. The financial distress model was first introduced by Altman (1968), known as the Altmant Z-Score. This model has been widely used and is still relevant for predicting a company that is experiencing financial difficulties, gray area, or healthy (Altman, et al, 2017). In 1995, Edward Altmant then modified the model, so that it can be used to predict 
the financial distress of manufacturing and non-manufacturing companies.

After the 1970s, several other models have been introduced to predict financial distress such as Springate (1978), Ohlson (1980); Zmijewski (1983); and Grover and Lavin (2001). The names of the models are given based on the name of the researcher who first introduced them. Tanjung (2020) analyzes financial distress using the discriminant model popularized by Altman in 1968, the Springate model in 1978, the logit model introduced by Ohlson in 1980, and the probit model developed by Zmijewski in 1984.

Research on financial distress has been carried out by several previous researchers. Previous researchers have used various models of financial distress analysis in their research. In these various studies, some only used one model in their research and some used many models in their research. Research that uses more than one model usually makes comparisons to determine the best model in the research. Some of the literature also examines the effect of financial distress analysis on other variables such as: stock prices, company delisting, and others.

From previous studies, no research has been found that examines the effect of financial distress, namely the Altman, Springate, and Zmijewski models on transportation stock returns on the IDX in 2016-2020. Research by Syamni et al. (2018) is almost similar to the research that will be tested in this discussion. Syamni et al. (2018) uses the same five models of financial distress as this study. In this study, the authors use three models of financial distress, namely Altman, Springate, and Zmijewski. In addition to analyzing this research, it also examines the effect of each model on stock prices. The differences between the studies of Syamni et al. (2018) with research in this discussion is located from the analysis tool used. Syamni et al. (2018) uses the panel data regression method, while this study uses a simple linear regression method with the object of research being the transportation sub-sector companies listed on the Indonesia Stock Exchange in 2016-2020.

In a literature review, several studies use the Altman or Altman model in measuring the financial distress of a company. There are studies that examine the effect of the results of financial distress from the model on stock prices. Altman model calculations on Indonesian coal companies indicate that three companies are healthy, 16 other companies are indicated to be bankrupt (Syamni et al., 2018). In addition, the results of testing the influence of the Altman model bankruptcy prediction on stock prices show results that have a significant effect. Analysis of the potential bankruptcy of the Altman model has a 


\section{Abdi Putra, Rangga Putra Ananto, Randy Heriyanto}

significant effect on coal stock prices (Abbas, Kusdianto, \& Inayah, 2020). The financial distress analysis of the Altman model has a partial effect on the stock price of property and real estate companies (Gantino \& Jonathan, 2020). Based on the description above, the following hypothesis is proposed:

H1: There is an effect of Altman's Financial distress model on transportation stock prices.

Syamni et al. (2018) tested the effect of the Springate model's bankruptcy prediction on coal stock prices. The analysis carried out shows that the Springate model has no significant effect on the stock price. Analysis of the potential for bankruptcy of the Springate model has no effect on coal stock prices (Abbas et al., 2020). The financial distress analysis of the Springate model has a partial effect on the stock price of property and real estate companies (Gantino \& Jonathan, 2020). The bankruptcy analysis of the Springate model has an influence on oil and coal mining stock prices (Darmayanti et al., 2020). Based on the description above, the following hypothesis is proposed:

$\mathrm{H} 2$ : There is an effect of financial distress on the Springate model on transportation stock prices.

Syamni et al. (2018) found that the effect of the Zmijewski model's potential bankruptcy prediction on coal stock prices has a significant effect. Zmijewski's analysis of financial distress does not partially affect stock prices of property and real estate companies (Gantino \& Jonathan, 2020). Zmijewski model bankruptcy prediction analysis has no effect on oil and coal mining stock prices (Darmayanti et al., 2020). Based on the description above, the following hypothesis is proposed:

H3 : There is an effect of Zmijewski's financial distress model on transportation stock prices.

\section{Research Method}

In this study, the population is all transportation sub-sector companies listed on the Indonesia Stock Exchange. In determining the sample of this study using purposive sampling. The sample criteria used in this study are as follows:

1. Companies that have been listed in 2015.

2. Transportation sub-sector companies that publish annual financial reports as of December 31 every year in the 2015-2020 period.

3. Have a negative profit of at least two consecutive years in the $2016-2020$ period (Ananto, 2020).

4. Have complete stock price data. 
The source of data in this study is the financial statements of companies in the transportation sub-sector in Indonesia. Financial data taken is data for 2015-2020. Financial report data is obtained from the IDX's official website (www.idx.co.id) or through the company's official website or credible website that presents financial reports. In addition, data related to GNP is obtained from the website www.macrotrends.net. For stock price data obtained from the site www.finance.yahoo.com. From the data obtained then processed into.

The data collection method used is the documentation method. The documentation method is carried out by obtaining data from written sources in the form of journals, books, documents, regulations, meeting minutes, and others (Sugiyono, 2013).

\section{Result and Discussion}

\section{Altman Model}

Table 1. Kolmogorov-Smirnov 1 . test

One-Sample Kolmogorov-Smirnov Test

\begin{tabular}{|c|c|c|}
\hline & & $\begin{array}{l}\text { Unstandardize } \\
\text { d Residual }\end{array}$ \\
\hline \multicolumn{2}{|l|}{$\bar{N}$} & 73 \\
\hline \multirow[t]{2}{*}{ Normal Parameters ${ }^{a, b}$} & Mean & ,0000000 \\
\hline & Std. Deviation & ,07836033 \\
\hline Most & ExtremeAbsolute & 126 \\
\hline \multirow[t]{2}{*}{ Differences } & Positive & 117 \\
\hline & Negative &,- 126 \\
\hline \multicolumn{2}{|l|}{ Test Statistic } & 126 \\
\hline \multicolumn{2}{|l|}{ Asymp. Sig. (2-tailed) } &, $006^{c}$ \\
\hline \multirow{3}{*}{$\begin{array}{l}\text { Monte Carlo } \\
\text { tailed) }\end{array}$} & (2-Sig. & $179^{d}$ \\
\hline & ConfidenceLower Bound & 170 \\
\hline & Upper Bound & 189 \\
\hline
\end{tabular}

a. Test distribution is Normal.

b. Calculated from data.

c. Lilliefors Significance Correction.

d. Based on 10000 sampled tables with starting seed 334431365.

Source: data processed 
From the table above, it is known that the significance value of the Kolmogorov-Smirnov test is 0.179 . The significance value is greater than the significant 0.05 . This indicates that the data has been normally distributed.

Table 2. Durbin-Watson test

Model Summary

\begin{tabular}{llllll} 
Model & $\mathrm{R}$ & R Square & $\begin{array}{l}\text { Adjusted } \\
\text { Square }\end{array}$ & $\begin{array}{l}\text { RStd. Error of } \\
\text { the Estimate }\end{array}$ & Durbin-Watson \\
\hline 1 &, $120^{\mathrm{a}}$ &, 014 &, 001 &, 07891 & 1,891 \\
\hline
\end{tabular}

a. Predictors: (Constant), ALTMAN1

b. Dependent Variable: RETURN1

Source: data processed

From table 2. Durbin-Watson test results show that the Durbin-Watson (DW) value is 1.891. Autocorrelation does not occur if the value of $\mathrm{dU}<\mathrm{DW}<4$ $d U$. To find the value of $d U$, the Durbin-Watson table is used. The number of observations in this study was 73 with the number of independent variables as much as one variable and a significance of $5 \%$. Based on the DW table, the dU value is 1.6479. To obtain a 4-dU value, 4-1.6479 is equal to 2.3521. After the dU and 4-dU values are obtained, the equation $1.6479<1.891<2.3521$ is obtained. These results indicate that there is no autocorrelation.

Table 3. Glejser test results heteroscedasticity Coefficients $^{a}$

\begin{tabular}{|c|c|c|c|c|c|}
\hline & $\begin{array}{l}\text { Unstandardiz } \\
\text { Coefficients }\end{array}$ & & $\begin{array}{l}\text { Standardized } \\
\text { Coefficients }\end{array}$ & & \\
\hline Model & B & Std. Error & Beta & $t$ & Sig. \\
\hline (Constant) & ,102 & ,362 & & ,282 & ,779 \\
\hline ALTMAN1 &,- 009 & ,072 &,- 015 &,- 123 & ,902 \\
\hline
\end{tabular}

a. Dependent Variable: ABS

Source: data processed

From table 3 it is known that the independent variable Altman has a significance of 0.902 . The significance value is greater than the significant 0.05 . This indicates that there is no heteroscedasticity or homoscedasticity in the observation data. 
Table 4. Altman Correlation and Stock Return

Correlations

\begin{tabular}{lll|l} 
& \multicolumn{2}{c}{ RETURN1 } & ALTMAN1 \\
\hline RETURN1 & Pearson Correlation & 1 &, 120 \\
\cline { 2 - 4 } & Sig. (2-tailed) & &, 312 \\
\cline { 2 - 4 } & $\mathrm{N}$ & 73 & 73 \\
\hline ALTMAN1 & Pearson Correlation &, 120 & 1 \\
\hline & Sig. (2-tailed) &, 312 & \\
\hline & $\mathrm{N}$ & 73 & 73 \\
\hline
\end{tabular}

Source: data processed

From table 4 it is known that the value of the Pearson correlation coefficient is 0.120 . The direction of the correlation of the resulting is a positive correlation. This positive relationship indicates that there is a relationship when the Altman value increases, the stock return will also increase. However, the correlation coefficient figures show a weak relationship because the positive correlation value is smaller than 0.5 . The significance resulting from testing the relationship between the results of the Altman model score and stock returns is 0.312 . From this it can be concluded that the relationship between the Altman model of financial distress and stock returns has a weak and positive relationship and is not significant.

Table 5. Partial Test

Coefficients $^{\mathrm{a}}$

\begin{tabular}{|c|c|c|c|c|c|}
\hline & $\begin{array}{l}\text { Unstandardiz } \\
\text { Coefficients }\end{array}$ & & $\begin{array}{l}\text { Standardized } \\
\text { Coefficients }\end{array}$ & & \\
\hline Model & B & Std. Error & Beta & $\mathrm{t}$ & Sig. \\
\hline (Constant) & ,719 & ,536 & & 1,341 & ,184 \\
\hline ALTMAN1 & 108 & 106 & 120 & 1,019 & ,312 \\
\hline
\end{tabular}

a. Dependent Variable: RETURN1

Source: data processed

Partial test results show that the resulting coefficient is 0.108 . This figure shows that there is a positive effect of each increase in Altman's score on stock returns of 0.108 . From the resulting significance value, it shows that there is an insignificant effect of the Altman model of financial distress on transportation stock returns. This is because the significance value of the t-test of 0.312 is greater than the significance of 0.025 . It can be concluded that the Altman model 
of financial distress has a positive and insignificant effect on transportation stock returns.

From the results of the coefficient of determination test, the R2 value is 0.014. This shows that the influence of the Altman model of financial distress on stock returns is $1.4 \%$. The remaining $98.6 \%$ is influenced by other factors. The following is the resulting regression model:

$$
\mathrm{Y}=0.719+0.108 \text { Altman }+\mathrm{e}
$$

Information:

$Y=$ stock return

Altman = Altman Model Value

e $=$ error rate

Based on the results of the $T$ test that the resulting model is not reliable because the significance value is greater than 0.025 . Therefore, the simple regression model above should not be used in projecting stock returns.

\section{Springate Models}

Table 6. Kolmogorov-Smirnov 2 . test

One-Sample Kolmogorov-Smirnov Test

Unstandardized

Residual

\begin{tabular}{|c|c|c|}
\hline $\mathrm{N}$ & & 76 \\
\hline \multirow[t]{2}{*}{ Normal Parameters ${ }^{a, b}$} & Mean & ,0000000 \\
\hline & Std. Deviation & 09289846 \\
\hline \multirow{3}{*}{$\begin{array}{ll}\text { Most } & \text { Extreme } \\
\text { Differences } & \end{array}$} & Absolute & 151 \\
\hline & Positive & ,096 \\
\hline & Negative &,- 151 \\
\hline \multicolumn{2}{|l|}{ Test Statistic } & 151 \\
\hline \multicolumn{2}{|l|}{ Asymp. Sig. (2-tailed) } &, $000^{c}$ \\
\hline \multirow{3}{*}{$\begin{array}{l}\text { Monte Carlo } \\
\text { tailed) }\end{array}$} & Sig. & $055^{d}$ \\
\hline & ConfidenceLower Bound & ,049 \\
\hline & Upper Bound & ,061 \\
\hline
\end{tabular}

a. Test distribution is Normal.

b. Calculated from data.

c. Lilliefors Significance Correction.

d. Based on 10000 sampled tables with starting seed 303130861.

Source: data processed 
From the table above, it is known that the significance value of the Kolmogorov-Smirnov test is 0.55 . The significance value is greater than the significant 0.05 . This indicates that the data has been normally distributed.

Table 7. Durbin-Watson 2 . test

\begin{tabular}{cl|llll}
\multicolumn{3}{c}{ Model Summary } & & Adjusted & \multicolumn{2}{c}{ RStd. Error ofDurbin- } \\
Model & $R$ & R Square & Square & the Estimate & Watson \\
\hline 1 &, $187^{\mathrm{a}}$ &, 035 &, 022 &, 09352 & 2,300 \\
\hline
\end{tabular}
a. Predictors: (Constant), SPRINGATE1
b. Dependent Variable: RETURN1

Source: data processed

From table 7. Durbin-Watson test results show that the Durbin-Watson (DW) value is 2,300. Autocorrelation does not occur if the value of $d U<D W<4$ $\mathrm{dU}$. To find the value of $\mathrm{dU}$, the Durbin-Watson table is used. The number of observations in this study was 70 with the number of independent variables as much as one variable and a significance of $5 \%$. Based on the DW table, the dU value is 1.6561 . To obtain a 4-dU value, 4-1.6561 is equal to 2.3439. After the $d U$ and 4-dU values are obtained, the equation $1.6561<2.300<2.3439$ is obtained. These results indicate that there is no autocorrelation.

Table 8. Glejser test results heteroscedasticity 2

Coefficients $^{\mathrm{a}}$

\begin{tabular}{|c|c|c|c|c|c|c|}
\hline \multirow{2}{*}{\multicolumn{2}{|c|}{ Model }} & \multicolumn{2}{|c|}{$\begin{array}{l}\text { Unstandardized } \\
\text { Coefficients }\end{array}$} & \multirow{2}{*}{$\begin{array}{r}\text { Standardized } \\
\text { Coefficients } \\
\text { Beta }\end{array}$} & \multirow[b]{2}{*}{$\mathrm{t}$} & \multirow[b]{2}{*}{ ig. } \\
\hline & & B & Std. Error & & & \\
\hline & (Constant) &,- 046 &, 123 & &,- 376 & 708 \\
\hline & SPRINGATE1 &, 063 & 071 & 103 & ,895 & 374 \\
\hline
\end{tabular}

a. Dependent Variable: ABS

Source: data processed

From table 8. it is known that the independent variable Springate has a significance of 0.374 . The significance value is greater than the significant 0.05 . This indicates that there is no heteroscedasticity or homoscedasticity in the observation data. 
Table 9. Springate Correlation and Stock Return

Correlations

\begin{tabular}{cll|l} 
& & SPRINGA & RETUR \\
& & TE1 & N1 \\
\hline SPRINGATE1 & Pearson Correlation & 1 &,- 187 \\
\cline { 2 - 4 } & Sig. (2-tailed) & &, 105 \\
\cline { 2 - 4 } & $\mathrm{N}$ & 76 & 76 \\
\hline RETURN1 & Pearson Correlation &,- 187 & 1 \\
\cline { 2 - 4 } & Sig. (2-tailed) &, 105 & 76 \\
\hline
\end{tabular}

Source: data processed

From table 9. it is known that the value of the Pearson correlation coefficient is -0.187 . The direction of the correlation of the resulting is a negative correlation. This negative relationship indicates that there is a relationship when the Springate value increases, the stock return will decrease or vice versa. However, the correlation coefficient figures show a weak relationship because the negative correlation value is greater than -0.5 . The significance resulting from testing the relationship between the scores of the Springate model and stock returns is 0.105 .

Table 10. Partial Test 2

Coefficients $^{\mathrm{a}}$

\begin{tabular}{|c|c|c|c|c|c|}
\hline \multirow[b]{2}{*}{ Model } & \multicolumn{2}{|c|}{$\begin{array}{l}\text { Unstandardized } \\
\text { Coefficients }\end{array}$} & \multirow{2}{*}{$\begin{array}{l}\text { Standardized } \\
\text { Coefficients } \\
\text { Beta }\end{array}$} & \multirow[b]{2}{*}{$\mathrm{t}$} & \multirow[b]{2}{*}{ ig. } \\
\hline & B & Std. Error & & & \\
\hline (Constant) & 1,533 & 172 & & 8,929 & 000 \\
\hline SPRINGATE1 &,- 162 & ,099 &,- 187 & $-1,640$ & 105 \\
\hline
\end{tabular}

a. Dependent Variable: RETURN1

Source: data processed

Partial test results show that the resulting coefficient is -0.162 . This figure shows that there is a negative effect of any increase in the Springate score on stock returns of 0.162 . From the resultant significance value, it shows that there is no significant effect of Springate's financial distress model on transportation stock returns. This is because the significance value of the t-test of 0.105 is greater than the significance of 0.025 . It can be concluded that the financial distress of the Springate model has a negative and insignificant effect on 
transportation stock returns. From the results of the coefficient of determination test, the $\mathrm{R} 2$ value is 0.035 . This shows that the influence of the Springate model of financial distress on stock returns is $3.5 \%$. The remaining $96.5 \%$ is influenced by other factors. Here is the resulting model

$$
\mathrm{Y}=1.533-0.162 \text { Springate }+\mathrm{e}
$$

Information:

$\mathrm{Y}=$ stock return

Springate $=$ Springate Model Value

e $=$ error rate

Based on the results of the $T$ test that the resulting model is not reliable because the significance value is greater than 0.025 . From the equation, it is known that if the Springate value is zero, the stock return is estimated at 5.218. Because the resulting model is not reliable, it is better not to use the resulting model to predict stock returns.

\section{Zmijewski Models}

Table 11. Kolmogorov-Smirnov 4 . test

One-Sample Kolmogorov-Smirnov Test

Unstandardize

d Residual

\begin{tabular}{|c|c|c|}
\hline $\mathrm{N}$ & & 77 \\
\hline \multirow{2}{*}{$\begin{array}{l}\text { Normal } \\
\text { Parameters }^{\mathrm{a}, \mathrm{b}}\end{array}$} & Mean & ,0000000 \\
\hline & Std. Deviation & 07302552 \\
\hline \multirow{3}{*}{$\begin{array}{l}\text { Most } \\
\text { Differences }\end{array}$} & Absolute & 132 \\
\hline & Positive & 113 \\
\hline & Negative &,- 132 \\
\hline \multicolumn{2}{|l|}{ Test Statistic } & 132 \\
\hline \multicolumn{2}{|l|}{ Asymp. Sig. (2-tailed) } &, $002^{c}$ \\
\hline \multirow{3}{*}{$\begin{array}{l}\text { Monte } \\
\text { tailed) }\end{array}$} & -Sig. &, $128^{d}$ \\
\hline & ConfidenceLower Bound & 120 \\
\hline & Upper Bound & 137 \\
\hline
\end{tabular}

a. Test distribution is Normal.

b. Calculated from data.

c. Lilliefors Significance Correction.

d. Based on 10000 sampled tables with starting seed 2048628469.

Source: data processed 
From the table above, it is known that the significance value of the Kolmogorov-Smirnov test is 0.128 . The significance value is greater than the significant 0.05 . This indicates that the data is normally distributed

Table 12. Durbin-Watson 4 test

Model Summary

\begin{tabular}{llllll} 
& & & Adjusted & RStd. Error of \\
Model & $R$ & R Square & Square & the Estimate & Durbin-Watson \\
\hline 1 &, $118^{\mathrm{a}}$ &, 014 &, 001 &, 07351 & 1,903 \\
\hline
\end{tabular}

a. Predictors: (Constant), ZMIJEWSKI1

b. Dependent Variable: RETURN1

Source: data processed

From table 12, the Durbin-Watson test results show that the DurbinWatson (DW) value is 1.903. Autocorrelation does not occur if the value of $d U<$ $D W<4-d U$. To find the value of $d U$, the Durbin-Watson table is used. The number of observations in this study was $\mathbf{7 7}$ with the number of independent variables as much as one variable and a significance of $5 \%$. Based on the DW table, the dU value is 1.6561. To obtain a 4-dU value, 4-1.6561 is equal to 2.3439 . After the dU and 4-dU values are obtained, the equation $1.6561<1.903<2.3439$ is obtained. These results indicate that there is no autocorrelation.

Table 13. Glejser test results heteroscedasticity 4 Coefficients $^{\mathrm{a}}$

\begin{tabular}{llrlr|l|l} 
& \multicolumn{2}{c}{$\begin{array}{l}\text { Unstandardized } \\
\text { Coefficients }\end{array}$} & \multicolumn{2}{l}{$\begin{array}{l}\text { Standardized } \\
\text { Coefficients }\end{array}$} & & \\
Model & & B & Std. Error & Beta & t & Sig. \\
\hline (Constant) &, 054 &, 054 & &, 999 &, 321 \\
\hline ZMIJEWSKI1 &,- 001 &, 020 &,- 004 &,- 034 &, 973 \\
\hline
\end{tabular}

a. Dependent Variable: ABS

Source: data processed

From table 13. it is known that the independent variable Zmijewski has a significance of 0.973 . The significance value is greater than the significant 0.05 . This indicates that there is no heteroscedasticity or homoscedasticity in the observation data. 
Table 14. Zmijewski Correlation and Stock Return

Correlations

\begin{tabular}{llc|c} 
& & ZMIJEWSKI1 & RETURN1 \\
\hline ZMIJEWSKI1 & Pearson Correlation & 1 &,- 118 \\
\cline { 2 - 4 } & Sig. (2-tailed) & &, 307 \\
\cline { 2 - 4 } & $\mathrm{N}$ & 77 & 77 \\
\hline RETURN1 & Pearson Correlation &,- 118 & 1 \\
\cline { 2 - 4 } & Sig. (2-tailed) &, 307 & 77 \\
\cline { 2 - 4 } & $\mathrm{N}$ & 77 & \\
\hline
\end{tabular}

Source: data processed

From table 14. it is known that the value of the Pearson correlation coefficient is -0.118 . The direction of the correlation of the resulting is a negative correlation. This negative relationship indicates that there is a relationship when the Zmijewski value increases, the stock return will decrease or vice versa. However, the correlation coefficient figures show a weak relationship because the negative correlation value is greater than -0.5 . The significance resulting from testing the relationship between the results of the Zmijewski model score with stock returns is 0.307 . From this, it can be concluded that the relationship between the Zmijewski model of financial distress and stock returns has a weak and negative relationship and is not significant.

Table 15. 3 Partial Test

Coefficients $^{\mathrm{a}}$

\begin{tabular}{|c|c|c|c|c|c|}
\hline & $\begin{array}{l}\text { Unstandardiz } \\
\text { Coefficients }\end{array}$ & & $\begin{array}{l}\text { Standardized } \\
\text { Coefficients }\end{array}$ & & \\
\hline Model & B & Std. Error & Beta & $\mathrm{t}$ & Sig. \\
\hline (Constant) & 1,343 & 077 & & 17,346 & ,000 \\
\hline ZMIJEWSKI1 &,- 029 & ,028 &,- 118 & $-1,029$ & ,307 \\
\hline
\end{tabular}

a. Dependent Variable: RETURN1

Source: data processed

Partial test results show that the resulting coefficient is -0.029 . This figure shows that there is a negative effect of any increase in Zmijewski's score on stock returns of 0.029 . From the resulting significance value, it shows that there is no significant effect of Zmijewski's financial distress model on transportation stock returns. This is because the significance value of the t-test of 0.307 is greater than the significance of 0.025 . It can be concluded that the Zmijewski model of 
financial distress has a negative and insignificant effect on transportation stock returns. From the results of the coefficient of determination test, the $\mathrm{R} 2$ value is 0.014 . This shows that the effect of Zmijewski's model of financial distress on stock returns is $1.4 \%$. The remaining $98.6 \%$ is influenced by other factors. The following is the resulting regression model:

$$
\mathrm{Y}=1.343-0.029 \text { ZMIJEWSKI +e }
$$

Information:

$\mathrm{Y}=$ stock return

ZMIJEWSKI = Zmijewski Model Value

$\mathrm{e}=$ error rate

From this equation, it is known that if the Zmijewski value is zero, the stock return is estimated to be 1.343. Based on the results of the $T$ test that the resulting model is not reliable because the significance value is greater than 0.025 . Therefore, this model should not be used to project stock returns.

The results of hypothesis testing indicate that the significance value of the Altman model on stock prices is 0.312 . This value indicates that there is no significant effect of Altman's financial distress model on stock returns of transportation companies listed on the IDX in 2016-2020. The effect of the Altman model is 0.108 positively. This indicates that if the calculation output of the Altman model increases by one unit, the company's stock return will also increase by 0.108 . In another sense, if the company is getting healthier or avoiding difficulties, the stock return will increase.

In line with the results of the influence test, the correlation test shows that there is no significant relationship between financial distress in the Altman model and transportation stock returns. This is because the significance value of the Altman model for the correlation test is the same as the significance of the correlation test of 0.108 . From the two tests, it can be seen that the influence test and the relationship test between the Altman model of financial distress are not significant.

PT Eka Sari Lorena Tbk (LRNA) is a company that is included in the transportation sector. In 2017 LRNA had a WCTA ratio of 0.043 . If the WCTA is multiplied by the WCTA coefficient (X1) of 6.56 , the value is 0.283 . The ratio of retained earnings to total assets (X2) LRNA is -0.098 . If this value is multiplied by a coefficient of 3.26 , a value of -0.319 is obtained. The third ratio is EBIT to total assets, the resulting company value is -0.146 . If this third ratio is multiplied by a coefficient of 6.72 , the value is -0.981 . The fourth ratio is BVE/BVL, this ratio has a value of 4,688 . If this ratio is multiplied by a coefficient of 1.05 , the value is 
4.922. Overall financial distress at LRNA companies in 2017 had a value of 3,905. This shows that in 2017 LRNA issuers did not experience financial distress.

In 2017 LRNA issuers had a stock return of $-57.3 \%$. This is contrary to the condition of companies that do not experience financial distress according to the Altman model. Market conditions that are opposite to the company's conditions indicate that investors do not pay attention to the Altman model of financial distress in their investment decisions. This explains that the relationship and the influence of the Altman model of financial distress analysis on stock returns are not significant in influencing investor decisions. In addition, the cause of the insignificance of the Altman model is that there are companies that are in the $15.3 \%$ gray area.

The results of this study are different from previous studies which state that there is a significant influence between the Altman model of financial distress on stock prices. These studies include (Syamni et al., 2018) which predict the potential for bankruptcy of the Altman model on coal mining stock prices. Abbas et al., (2020) who found that there was a significant effect of the Altman model bankruptcy prediction on coal stock prices. gantino \& Jonathan (2020) in their research also states that the Altman model of financial distress has a significant effect on stock prices of property and real estate companies.

The results of hypothesis testing indicate that the significance value of the Springate model on stock prices is 0.105 . This value indicates that there is no significant effect of Springate's financial distress model on stock returns of transportation companies listed on the IDX in 2016-2020. In addition to the influence test, this study also looks at the relationship between financial distress in the Springate model on the return of transportation stocks

In line with the results of the influence test, the correlation test shows that there is an insignificant relationship between financial distress in the Springate model and transportation stock returns. This is because the significance value of the Springate model for the correlation test is the same as the significance of the correlation test of 0.105 . From the two tests, it can be seen that the influence test and the relationship test between the Springate model of financial distress and stock returns are not significant.

PT Express Trasindo Utama Tbk (TAXI) is one of the companies included in the transportation company. In 2018 this TAXI issuer produced an X1 value of 0.105 ; $\mathrm{X} 2$ value is -1.738 ; $\mathrm{X} 3$ value is -0.454 ; and $\mathrm{X} 4$ value of 0.076 . Overall, TAXI in 2018 produced a financial distress value of the Springate model -2.011. From the results of the Springate score, it can be seen that the company is in a state of financial distress. This is because the resulting score is smaller than 0.862 . 


\section{Abdi Putra, Rangga Putra Ananto, Randy Heriyanto}

In 2018 the issuer of TAXI had a stock return of $80 \%$. This condition is in contrast to the condition of companies experiencing financial distress. The insignificantness of the Springate model corresponds to the insignificantness of the Altman model. This is because in the Springate model there are several ratios that are the same as the Altman model. So when Altman is not significant then Springate will have great potential to produce the same result. This explains that the relationship and influence of the Springate model of financial distress analysis on stock returns is not significant.

The results of this study are not in line with research (Gantino \& Jonathan, 2020) which shows that the Springate model has a partially significant effect on stock prices of property and real estate companies. The same results were also shown in research (Darmayanti et al., 2020) on oil and coal mining companies. The results, which are consistent with this study, show that there is no significant effect of Springate's financial distress model on coal stock prices (Abbas et al., 2020). The results that have no effect are also shown by Syamni et al. (2018) which examines the significant effect of the Springate model bankruptcy prediction on coal stock prices.

The test of the effect of Zmijewski's financial distress model on transportation stock returns has a significance of 0.307 . The result of this test is greater than the significance of 0.025 . This value indicates that there is no significant effect of Zmijewski's financial distress model on transportation stock returns. In addition to the influence test, this study also uses a correlation test or testing the relationship between two variables.

In line with the results of the influence test, the correlation test shows that there is no significant relationship between financial distress in the Zmijewski model and transportation stock returns. This is because the significance value of the Zmijewski model for the correlation test is the same as the significance of the correlation test of 0.307. From the two tests, it can be seen that the influence test and the relationship test between Zmijewski's financial distress model on stock returns are not significant.

The return on assets (ROA) of PT Tanah Laut Tbk (INDX) in 2018 was 1.022; when multiplied by the $X 1$ coefficient of 4.5 , the $X 1$ value is -4.601 . Debt ratio in 2018 was 0.006 ; when multiplied by the $X 2$ coefficient of 5.7 , the $X 2$ value of 0.036 is obtained. The current ratio in 2018 is 421,994; when multiplied by the $X 3$ coefficient of 0.004 then the $X 3$ value is 1.688 . Overall, the Zmijewski INDX model's financial distress in 2018 was -1.351 . From these results it is known 
that according to Zmijewski INDX 2018 did not experience financial difficulties.

In 2018 the INDX issuer had a stock return of $-13.2 \%$. This is contrary to the condition of companies that do not experience financial distress according to the Zmijewski model. The insignificance of the Zmijewski model is due to the lack of attention to the company's ROA ratio. This can be seen when the ROA is negative, the stock return actually shows a positive change. In addition, the financial ratios used in the Zmijewski model are also the least, only three financial ratios. The results of the calculation of financial distress also show that Zmijewski predicts companies in financial distress at the least.

In line with this research, the Zmijewski model of financial distress has no significant effect on stock prices of property and real estate companies (Gantino \& Jonathan, 2020). The bankruptcy prediction of the Zmijewski model also has no significant effect on oil and coal mining stock prices (Darmayanti et al., 2020). Different research results are shown by Syamni et al. (2018) that there is a significant effect of the Zmijewski model's bankruptcy prediction on coal stock prices. However, because the significance of the study is not significant, stakeholders can ignore or continue to use the Zmijewski model according to their respective interests.

\section{Conclusion}

This study examines the effect of the Altman, Springate, and Zmijewski financial distress models on the stock prices of transportation issuers in 20162020. This study used an initial sample of 17 companies with a total of 85 observations. Then from each model analyzed separately using correlation and simple regression. From the results of the study, the following conclusions were obtained:

a) Altman's financial distress model has no significant effect on stock prices of Indonesian transportation issuers. This causes hypothesis one to be rejected.

b) Springate's financial distress model has no significant effect on the stock price of Indonesian transportation issuers. This causes hypothesis two to be rejected.

c) Zmijewksi's financial distress model has no effect on the stock price of Indonesian transportation issuers. This causes hypothesis three to be rejected. 


\section{References}

Abbas, Dirvi Surya, Kusdianto, Kusdianto, \& Inayah, Lailatul. (2020). PENGARUH ALTMAN Z-SCORE" DAN SPRINGATE S-SCORE SEBAGAI ALAT PREDIKSI POTENSI KEBANGKRUTAN TERHADAP HARGA SAHAM (pada perusahaan batubara yang listing di bursa efek indonesia periode 2016-2018). Dynamic Management Journal, 4(1). https://doi.org/10.31000/dmj.v4i1.2083

Altman, Edward I. (1968). FINANCIAL RATIOS, DISCRIMINANT ANALYSIS AND THE PREDICTION OF CORPORATE BANKRUPTCY EDWARD. The Journal of Finance, 4(1), 312-312. https://doi.org/10.1111/j.1540-6261.1974.tb00057.x

Ananto, Rangga Putra. (2020). Penggunaan Model Springate untuk Mendeteksi Penurunan Kinerja Keuangan (Financial Distress) Sektor Pertambangan di Bursa Efek Indonesia. Jurnal Akuntansi Keuangan Dan Bisnis, 13(1), 61-70.

Beaver, William H. (1968). Market Prices, Financial Ratios, and the Prediction of Failure. Journal of Accounting Research, 6(2), 179.

https://doi.org/10.2307/2490233

Darmayanti, Novi, Rosyida, Isnaini Anniswati, \& Fauziyah, Eti Nasrotul. (2020). Analisis Prediksi Kebangkrutan Terhadap Harga Saham Dengan Model Zmijewski Dan Springate (Studi Empiris Pada Perusahaan Sub Sektor Pertambangan Minyak Dan Gas Bumi Dan Batubara Yang Tercatat Di Bei Tahun 2016-2018). Ekonika : Jurnal Ekonomi Universitas Kadiri, 5(2), 157. https://doi.org/10.30737/ekonika.v5i2.848

Effendi, Ria. (2018). Analisis Prediksi Kebangkrutan Dengan Metode Altman, Springate, Zmijewski, Foster, Dan Grover Pada Emiten Jasa Transportasi. Jurnal Akuntansi, Manajemen Dan Bisnis (PARSIMONIA), 4(3), 307-319.

Gantino, Rilla, \& Jonathan, Ivan. (2020). Pengaruh Hasil Altman Z-Score, Springate, Dan Zmijewski Sebagai Alat Prediksi Kebangkrutan Financial Distress) Terhadap Harga Saham (Studi Empiris Perusahaan Property \& Real Estate dan Food and Beverages yang Terdaftar di Bursa Efek Indonesia Periode 2014. Jurnal Ratri (Riset Akuntansi Tridinanti), 1(2).

Irama, Ova Novi. (2018). Pengaruh Potensi Kebangkrutan Terhadap Harga Saham Pada Perusahaan Manufaktur Yang Terdaftar Di Bursa Efek Indonesia. Jurnal Bisnis Net, 1(1).

Mukaromah, Mojang Al, Yuliari, Kartika, \& Arifin, Mohammad. (2019). Dampak Keberadaan Transportasi On Line Terhadap Kondisi Sosial Ekonomi Transportasi Konvesional Di Kota Kediri Mojang. Jimek, 2(2), 168-181.

Ohlson, James A. (1980). Financial Ratios and the Probabilistic Prediction of Bankruptcy. Journal of Accounting Research, 18(1), 109. https://doi.org/10.2307/2490395

Prasetyo, Vidya Rachmadhani, \& Widyawati, Dini. (2020). PENGARUH PREDIKSI KEBANGKRUTAN YANG DIHITUNG DENGAN Z- SCORE DAN S-SCORE TERHADAP HARGA SAHAM PADA PERUSAHAAN FOOD AND BEVERAGE. Jurnal IImu Dan Riset Akuntansi. 
Puspita, Desilya vita, Darmawan, Dwi Putra, \& Ustriyana, I. Nyoman Gede. (2016). Analisis Tingkat Kebangkrutan Model Altman dan Foster Pada Perusahaan Agribisnis di Bursa Efek Indonesia. E-Jurnal Agribisnis Dan Agrowisata, 5.

Ramadhani, Ayu Suci, \& Lukviarman, Niki. (2009). Perbandingan Analisis Prediksi Kebangkrutan Menggunakan Model Altman Pertama, Altman Revisi, dan Altman Modifikasi dengan Ukuran dan Umur Perusahaan sebagai Variabel Penjelas (Studi Pada Perusahaan Manufaktur yang Terdaftar di Bursa Efek Indonesia). Jurnal Siasat Bisnis, 13(1), 15-28. https://doi.org/10.20885/jsb.vol13.iss1.art2

Sajjan, Prof Rohini. (2016). Predicting Bankruptcy of Selected Firms By Applying Altman's Z-Score Model. International Journal of Research-Granthaalayah, 4(4), pp 152-158.

Syamni, Ghazali, Majid, M. Shabri Abdul, \& Siregar, Widyanana Verawaty. (2018). Bankruptcy Prediction Models and Stock Prices of the Coal Mining Industry in Indonesia. Etikonomi, 17(1), 57-68.

https://doi.org/10.15408/etk.v17i1.6559

Tanjung, Putri Renalita Sutra. (2020). COMPARATIVE ANALYSIS OF ALTMAN ZSCORE, SPRINGATE, ZMIJEWSKI AND OHLSON MODELS IN PREDICTING FINANCIAL DISTRESS. Multidisciplinary Research, (2), 126-137.

\title{
Copyright holder :
}

\author{
Abdi Putra, Rangga Putra Ananto, Randy Heriyanto (2021) \\ First publication right :
}

Devotion : Journal of Research and Community Service This article is licensed under: 